\title{
THE ROLE OF LEXICAL HOMOGENEITY IN THE POETRY RHYTHM OF HAZIN LAHIJI
}

\author{
O PAPEL DA HOMOGENEIDADE LEXICAL NO RITMO DA POESIA DE HAZIN \\ LAHIJI
}

\author{
EL PAPEL DE LA HOMOGENEIDAD LÉXICA EN EL RITMO DE LA POESÍA DE \\ HAZIN LAHIJI
}

\author{
Narges MORADGANJEH ${ }^{1}$ \\ Bijan ZAHIRI NAV ${ }^{2}$ \\ Shokrollah POURALKHAS ${ }^{3}$
}

\begin{abstract}
Hazin Lahiji is one of the prominent poets of the twelfth century AH (11031180). A poet who has been the center of many literary controversies and conflicts of his time, he is also a rhythm and a criterion for measuring the poems of his contemporaries, and the so-called "corrector", he is a personality that Indian grandee are proud to talk. The aim of this writing, with attention to the homogeneity of words in creating rhythm and integration into poetry and with analytical-descriptive method, and with formalistic approach, is to show how Hazin Lahiji creates the most rhythm from the beauties of rhetorical industries and the aspect of their order and coherence in their proper place and time, and how to connect the rhythm of poetry with other elements to add value to the sound and music of poems. And he uses a kind of understanding between his thought and sympathy with the audience to show the distinctive poetic language. To explain this issue, he organized disciplines under two general categories "imperfect" and "perfect balance" and examined the role of industries related to each category as a process of de-familiarization through the music of Hazin (sad) poems. The present study shows that Hazin Lahiji, with the knowledge of the aesthetic aspects of music word, has been able to affect the soul and spirit of the audience by all kinds of repetition and observing the appropriateness of words, choosing beautiful words in the right places to express himself poetically as much as possible and to release his words from the usual hierarchy and linearity.
\end{abstract}

KEYWORDS: Regularization. Poetry music. Vocabulary homogeneity. Repetition and balance. Hazin Lahiji.

RESUMO: Hazin Lahiji é um dos poetas proeminentes do século XII AH (1103-1180). Poeta que tem sido o centro de muitas controvérsias e conflitos literários de sua época, ele é também um ritmo e um critério para medir os poemas de seus contemporâneos, e o chamado "corretor", é uma personalidade que os grandees indianos tem orgulho de falar. O objetivo

${ }^{1}$ University of Mohaghegh Ardabili (UMA), Ardabil - Iran. PhD student of the Department of Persian Language and Literature. ORCID: https://orcid.org/0000-0002-5410-7335. E-mail: nmoradganjeh@gmail.com

${ }^{2}$ University of Mohaghegh Ardabili (UMA), Ardabil - Iran. Associate Professor of the Department of Persian Language and Literature. ORCID: https://orcid.org/0000-0002-1946-1814. E-mail: zahirinav@yahoo.com

${ }^{3}$ University of Mohaghegh Ardabili (UMA), Ardabil - Iran. Associate Professor of the Department of Persian Language and Literature. ORCID: https://orcid.org/0000-0002-7910-7075. E-mail: Pouralkhas@uma.ac.ir 
deste escrito, com atenção à homogeneidade das palavras na criação de ritmo e integração na poesia e com método analítico-descritivo, e com abordagem formalista, é mostrar como Hazin Lahiji cria o máximo de ritmo a partir das belezas das indústrias da retórica do aspecto de sua ordem e coerência em seu devido lugar e tempo, e como conectar o ritmo da poesia com outros elementos para agregar valor ao som e à música dos poemas. E ele usa uma espécie de compreensão entre seu pensamento e simpatia com o público para mostrar a linguagem poética distinta. Para explicar essa questão, ele organizou disciplinas sob duas categorias gerais "imperfeito" e "equilíbrio perfeito" e examinou o papel das indústrias relacionadas a cada categoria como um processo de desfamiliarização por meio da música de Hazin poemas (tristes). O presente estudo mostra que Hazin Lahiji, com o conhecimento dos aspectos estéticos da palavra musical, tem sido capaz de afetar a alma e o espírito do público por meio de todos os tipos de repetição, observando a adequação das palavras, escolhendo belas palavras nos lugares certos para expressar-se poeticamente o tanto quanto possivel e libertar suas palavras da hierarquia e linearidade usuais.

PALAVRAS-CHAVE: Regularização. Poesia musical. Homogeneidade de vocabulário. Repetição e equilíbrio. Hazin Lahiji.

RESUMEN: Hazin Lahiji es uno de los poetas prominentes del siglo XII d. C. (1103-1180). Poeta que ha sido el centro de muchas controversias y conflictos literarios de su tiempo, es también ritmo y criterio para medir los poemas de sus contemporáneos, y el llamado "corrector", tiene personalidad de la que los grandes indios se enorgullecen para hablar con él. El objetivo de esta escritura, con atención a la homogeneidad de las palabras en la creación de ritmo y la integración en la poesía y con método analítico-descriptivo, y con enfoque formalista; es mostrar cómo Hazin Lahiji crea el mayor ritmo a partir de las bellezas de las industrias retóricas y el aspecto de su orden y coherencia en su lugar y tiempo adecuados, y cómo conectar el ritmo de la poesía con otros elementos, con el fin de agregar valor a la sonido y musica de poemas. Y usa una especie de comprensión entre su pensamiento y la simpatía con el público para mostrar el lenguaje poético distintivo. Para explicar este tema, organizó las disciplinas en dos categorías generales "imperfecto" y "equilibrio perfecto" y examinó el papel de las industrias relacionadas con cada categoría como un proceso de des-familiarización a través de la música de los poemas Hazin (tristes). El presente estudio muestra que Hazin Lahiji, con el conocimiento de los aspectos estéticos de la música de palabra, ha podido afectar el alma y el espiritu de la audiencia mediante todo tipo de repetición y observando la idoneidad de las palabras y eligiendo palabras hermosas en el lugar correcto, y para expresarse poéticamente tanto como sea posible y liberar sus palabras de la jerarquía y linealidad habituales.

PALABRAS CLAVE: Regularización, Poesía musical, Homogeneidad de vocabulario, Repetición y equilibrio, Hazin Lahiji.

\section{Introduction}

If we consider poetry as the resurrection of words (SHAFI'I KADKANI, 2010, p. 42) and if the contribution of prosody rhythms, lines and rhymes in the evocation of words be undeniable and safe, without a doubt, the factor that distinguishes words and distinguishes the 
language of poetry from ordinary language would be music, by using this factor, a rhythmic and pleasant reverberation dominates the body of poetry and the secondary meanings of it sit in the listener's ear. Because music is the sound of the collision of poetic waves on the shore of this universe.

Expressing and describing emotions and expressing emotions are the motivation for creating music and poetry; these factors translate the souls of people and reflect the poet's meta-sensory experiences. Sabouri, in the context of the longevity of the connection between the art of music and poetry, and the overall result obtained from the study of the opinions of orators and researchers on the connection between poetry and music said:" regardless of undeniable correlation of sound and word, what most affirms the apparent relationship of musical poetry is the rythm of words in the poem... and before the prosody of Persian poetry literature is subjugated and rhyme observance becomes common in Persian poetry, Persian syllabic and melodic poems begin with a pleasant melody and then it has been harmonized with the sound of the harp and the river (SABURI, 2015)

From other perspectives, one can look at the connection between music and poetry, and that is the creation of beauty. Because, the field of poetic art (expression of transcendent thoughts) and the art of music to express inner emotions, have a lot in common and are intertwined. Both seek to create beauty; create beauty with the help of words and create beauty with the help of sounds; and the connection between sound, word, and song with the melody of music is undeniable. Because the melody of letters is a reverberation and melody that is created from proximity and accompaniment of special letters and order and sequence of sound in word and sentence. So said that music in the language of poetry begins with the music of the word, and poets choose words that produce music melody in the vicinity. Basically poetry is created to be enriched with it, from this view it is said in Greek and Latin as "enriched poetry" Arabic also says: Anshad means enriched poetry. In Persian, poetry is also a term. ... and we see that poets in the Islamic period hired people who wrote their poetry in the Shah's book and the caliphs should sang along, and one of the reasons for the connection between poetry and music is Hassan Ibne- Thabet is that who believes that poetry should be weighed against music in order to reveal its good and bad (ibid: 45). The word of sonnet and song and which is very common in the poetry of Persian poets and is synonymous with each other, all shows the connection between these two arts (music and poetry).

A text needs factors to be literary and to meet the standard of literature, factors that separate a text in a language from other texts that have no literary value. For this reason, sometimes rules are added to the exterior of the language to make the language stand out and 
differentiate, and the language, despite the specific music of the words and the rhythm of the pronouns, is distinguished and highlighted. As Safavi says: According to formalists, one of highlighting way is to increase the rule (SAFAVI, 2011, p. 46).

According to Sheklovski, for language familiarity; it is possible to accumulate difficult sounds and also to use rhythm in the poem (MAKARIK, 2014). The same tricks that the poet uses to create strangeness and freshness in language.

Babak Ahmadi says about highlighting and distinguishing words: The first point is that poetry is all "playing with language". It is rooted in the concept of "de-enrichment" and in this way linguistic tricks, poetic language tricks (use of rhythm, multiplicity of rhymes, lines, attention to phonetic music) highlight the word or words in the poem. They separate its everyday use, so that something alien becomes new and unique, and this removal of habits is de-familiarization (AHMADI, 2014). Therefore, language and poetic techniques add rules to ordinary language and by creating proportions, rhythm and phonetics combine balance and music with their words, and this balance is achieved through verbal repetition (SAFAVI: 2010).

The word balance is synonymous with the word repetition and is often used together. In fact, balance at any level is (phonetic, syntactic, and lexical) result of repetition. As Jahan Tigh says:

It is the external, internal and lateral level of the word and is the first step of the poet to highlight the word and distinguish it from the prose (JAHAN TIGH, 2001, p. 30).

Repetition has an undeniable role in creating beauty, without repetition, music notes and symmetries in architecture, painting and repetition of sounds, sounds and words to create poetry and art could not be created.

The importance of repetition and human desire to repeat and repetitive actions in Mirchaliadeh book:

People repeat these things because in the beginning of creation, they were sanctified by ancestors or gods. The ancient man, in all his conscious behavior, does not know what he has already done and tested by someone else. His whole life is an uninterrupted repetition of the actions started by others. Man's actions gain validity and reality only to the extent that he repeats the initial action. Man is only engaged in the repetition of creation. Over the course of a year, his religion has allegorically repeated all the stages of the universe that took place on the first day, keeping its memory alive during celebrations and feasts. Hegel has firmly claimed that things in the universe are always repeat themselves, there is nothing new under the blue sky [...] all human effort is to Suspicious of the primordial items in order to be safe from the evil times and to be able to make the events real (ELIADEH, 2005, p. 19-99). 
In order to resist historical and objective time and to join the holy and great time.

Examples of repetition have been used extensively in Avesta, in ancient Persian manuscripts, in Pahlavi books (in the minoye Kherad as a frequent question and answer), in folk poems and songs, in couplets, in religious texts and prayers. The poet increase the permanence and continuity of the sensory induction of his poem to convey his poetic emotions and experiences to the audience by his poetic art and the motivation that he creates in the reader. "Repetition" from a psychological point of view (based on the Atkinson-Schafer model (1968) is also the most important factor in the induction of thought and its perpetuation factor. According to it, the speech from sensory memory enters the short-term memory and is encoded phonetically. They will be erased after about 30 seconds. But the short-term memory data enters the long-term memory if it is repeated.

Since music is stable by repetition and diversity, each aspect of them is defined in internal music, in deep music, the coherence and strength of the poem and its originality are always stable, so that it is impossible to cling to it. The use of this art and its application in poetry, to a large amount depends on the artistic taste and talent of the poet, requires the poet to be influenced by his aesthetic passion, so that the poet's deep knowledge of beautiful structures about harmony of the components has the feature that whoever wants to find an admirable point in it, use the association of ideas. This type of poetry music is the most important realm of music and stability and cohesion embraces him towards a new range. The aesthetic foundations of many literary masterpieces lie in this type of music. Poetry critics, in explaining its effects, use terms such as eloquence, tonality and music and Russian formalists call it "orchestration (SHAFIEE KADKANI, 2000, p. 392). Inner music; together with other musical elements (rhythm, rhyme and line) completes the music of the poem.

\section{Purpose and objective}

The distinguishing factor of poetic language is the existence of imagination, rhythm and music of poetry, so; Alipour says to express the originality of music in the language of poetry: "According to Verlaine, music is first and foremost in poetry, and the fact that Andre Spear says about song: it is the dance of the mouth with words," is due to the originality of the work (ALIPOUR, 2008, p. 54). What provides the strength and coherence of poetry is the music of poetry, which, in addition to the rhythm of prosody and line and rhyme, it comes from the coordination between words, repetition of syllables and sounds and the use of aesthetic and original array. Therefore, it is not only the prosodic principles of Persian poetry 
that show the ancient connection between poetry and music, but also the rhythm of words and their proportion and correlation, is the true basis of this connection.

Without music, imagination and emotion of poetry and secondary meanings of poetry, which are the result of the poet's inner experiences, the opportunity will not be transferred and poetry will be reduced to the level of everyday conversation. Hazin Lahiji has enriched his poetic language by using these innovative tools and linguistic capacities and has proved his poetic language. Repetition and the resulting music is one of the main elements of poetry which is usually chosen spontaneously and unknowingly. For this reason, what determines the acoustic value of repetition is the way it is used in the context of speech; That is, a word that is repeated many times in a particular place of a beat or string has more musical value until repetition occurs in unpredictable situations. For this reason, what is important in examining the usual arrays is what creativity, literary taste, and aesthetics are reflected in their application.

The balance, at the level of the sounds and words of Lahiji' poem, is the result of his innate taste and talent. Contrary to what is stated in the description of Lahiji's sadness and style of writing about his diligence and desire to follow the works of the past and the style of famous poets, especially diligence in following the words and praising Hafez's thoughts, is the creation of different poetic aspects are derived from his innate talent, mental creativity, his literary taste, aesthetics and creativity .With the help of proportions and harmonies, the poet presents melodic and melodious words, a musical and effective form of words, accompanies the audience with emotions and imagination, inner experiences and transcendent poetic concepts and meanings, and conveys his experiences to the audience.

Hazin Lahiji, in every field of literature, especially in the field of music, has outstanding features that cause familiarity in his speech. "Repetition" with various musical aspects in music, and the use of special rhymes are verbal innovations and examples that requires another discussion.

\section{Literature review}

Few works are available on the analysis of Lahiji poems, and in recent years despite the popularity of new literary theories, including formalism and its many dimensions by researchers in the field of Persian language and literature, there is still no work directly related to critiqued formalist view of sad poems; But in the field of coherence and music creation of words, there are several works written by Gholam Hossein Gholam Hosseinzadeh and Hamed 
Norouzi. According to its authors, this paper examines the coherence factors from Halliday's point of view (which essentially seeks to show coherence factors in standard language, not literary language) along with syntactic balance. Syntactic balance is one of the balance types at the level of the inner music of poetry, which is related to the study of poetic music in terms of the use of various types of publishing, adjective numbering, heartache and photo industry at the level of companion and role replacement; But in the following and in the abstract of the article, the approach of the authors has changed and they have adopted a more comprehensive method for coherence, and that is, with semantic congruence and phonetic repetition on the outer, lateral and inner level. And it was right that the same method was mentioned from the beginning. As in the introduction of the article, the addition of coherence factors of the literary text to Holliday is mentioned as a research method. In practice many cohesion factors from this perspective; For example, citation (only one example without mentioning it), repetition of semantic components, substitution, omission and relevance of the article is not seen and has no evidence, perhaps that is why in the text of the article or in the conclusion section, answers to the questions raised in introduction is not seen and some general presented principles have no evidence in the article. In the opinion of the author, despite the valuable findings of this article, the scatter of selected criteria to prove coherence, the article deviates from the actual coherence and expected results. Another article is the article "Structurallexical unity of homogeneous sentences" (one of the syntactic patterns of music in Masnavi "written by Abolghasem Radfar and Mohammad Pak Nahad). The industry of arrangement and balance as the same sentences that have a single grammatical and lexical structure, create the music of Rumi's poems, has been the basis of research; and is part of the vocabulary at the level of internal music.

Another article written in the field of word creation music; "The role of complete lexical homogeneity in the poetry of Hamam Tabrizi" Which has been written by Jalil Tajlil and Fazel Abbaszadeh. As the name of the article implies, complete lexical homogeneity has been considered in the form of repetition of a linguistic form, repetition of some linguistic form in music-making of Hamam Tabrizi's poems, but other aspects of the music-making of poetry have not been studied that have an undeniable role in this category, and it is the rhyme of the poem that is discussed in the topic of incomplete homogeneity. Balance and parable are not presented in this article.Mohammad Barani's article titled "Poetry Music of Farrokhi Sistani" applied to the poetry music of this poet through the rhythm of prosody (which occupies a large part of the article), and syntactic repetitions, and from the literary industries that make up music like incomplete puns, superfluous puns, predicate puns, line puns and 
derivation puns, balance and analogy, adjective coordination, question and answer, and the imagery industry. In this article, despite the effort in introducing music-creating factors, the place of classifying music-creating factors is empty from a linguistic point of view, and that is why the role of all kinds of puns, composites and rejection and photography industries, similarity in listening and creating the music neglected, instead, the focus is on syntactic repetitions. Another valuable article is "Repetition, its Audio and Rhetorical Value" by Jaleh Motahidin, which examines repetition in the form of repetitive components (letters and syllables), puns, rhymes, and repetitive words.

\section{Research methods}

The method of our research in this article is analytical-descriptive method with a formalist approach. In this work we tried to determine the importance of poetry music, union of music and poetry and its role in repetition and homogeneity of words in poetry music of Lahigi poetry, for this reason we examine the meaning of homogeneities in two complete levels: in the form of phonetic repetition of a linguistic form such as types of conjugation, similarity of surroundings, rejection and photo, row (final rows, impossible rows of pronouns and contrasting row )and phonetic repetition of two or more linguistic forms( types of puns; Includes, complete, compound puns) and incomplete lexical homogeneity; types of rhymes on the surface of sentences; including adverbs, balances, parables, conjugation. Contrasting, unobtrusive, beginning and middle and by providing evidence, show that Hazin, by using a variety of industries, in creating the rhythm of words, in line with the content of the word, has transcended language from ordinary and everyday language to a special literary prominence.

\section{Results}

\section{Complete lexical homogeneity}

The complete homogeneity is that the word, group and sentence are repeated in one or more verses without any phonetic changes (Safavi, 2010, first v, 224). This artistic technique is essentially a complete phonetic similarity between two or more grammatical elements or the repetition of a single grammatical element, which is presented in the forms of complete homogeneity of a linguistic form and complete homogeneity of two or more linguistic forms. 


\section{Complete homogeneity of a linguistic form}

\section{Tashaboh-ol-atraf}

And that is when one of the words of the end of the first stanza is repeated at the beginning of the second stanza and one of the words of the end of the second stanza is repeated at the beginning of the third stanza, Qas Ali Haza (SHAMISA, 2004):

\section{Movement of the six frozen limbs}

Give that nut a candy, loose

The loose is the fetal ligament

Farzin plays the role of an animal

In this example, the last words of the syllables are repeated in the first syllable of the next stanza. Repetition of similar word has mutual influence; because the repetition is used in the right place, and with the contradictions and proportions that it has with the other words of the verse and has created a certain order, the melody and music of the words have also appeared more effectively. The rhythmic song accompanies him in accepting the meanings desired by the poet.

\section{Rejection and reverse, conversion and reverse}

It is to "divide a hemistich into two parts and repeat those two pieces in the other hemistich as reverse. Sometimes in the repetition of the pieces, there is a slight change and they may do this conversion in one hemistich (SHAMISA, 2007, p. 80):

Two, not to mention, the twois Ahuli But I am a prophet, a prophet is a guardian (Hazin, 2005)

When sad became more I take it less My heart mourned and I mourned the heart

In the above verses, part of the second stanza is repeated in reverse, and this caused the music as audible. In this, in the first example, "but" is subject and "prophet" is attributed. In the following example, the "prophet" is subject and "but" is attributed in the next example, the "heart" has subject role and the "I" has an augend role; But then, their role shifts and a new sentence appears, which is in syntactic balance with the first sentence. As can be seen, in these verses, the words are repeated by changing the syntactic role. 


\section{Line (final)}

It is a complete homogeneity that arises from the repetition of a single grammatical element (word, group, clause or sentence) with the same sequence and with the same phonetic, morphological, syntactic and semantic roles, at the end of the syllables or verses of the poem and after the rhyming word (HAGHSHENAS, 2011, p. 62).

Shafiee Kadkani says about line: line gives beauty and importance to poetry in several ways: 1- In terms of music 2- In terms of meanings and helping the poet's associations 3- In terms of creating novel combinations and metaphors in language ... and one of its important aspects is its musical aspect (SHAFI'I KADKANI, 2000, p. 138-142).

Line plays different roles in poetry; the line is always accompanied by a rhyme; the presence of line contributes in the richness of the prosodic rhythm, and in addition to being in harmony with the rhyme, it is often in harmony with the other words of the verse in terms of "consonant". Pause and lean is on the line. So; it is responsible for conveying the emotions of the poem to some extent, and in some cases it causes the defects to be omitted, and choosing the right line may not be ineffective in choosing other words and phrases of the poem. The line can also express the thoughts and ideas of the poet. The unfamiliarity of the line is that it is not used in ordinary language and is foreign to many minds. The line is used in Lahiji book as follows:

- Word (noun, verb, adjective, pronoun and adverb), group, current phrase, contrasting line, long line and sad special line.

\section{Words (noun, verb, adjective and pronoun)}

\section{Intelligence and patience and wisdom from hand work It's difficult to put these four hands together Morning came to my pub an oracle That should have been at the old man door}

As mentioned, sometimes the similarity of the line with other words of the verse, gives a special richness to the music of the poem and creates sound and letters in the poem. In the verse "Morning came to my pub an oracle "; the repetition of the long vowel "m" creates a special melody. Based on this verse and many evidences, Hazin Lahiji, in terms of content and form of poetry, has followed Hafiz. In the continuation and in the third verse, the word "alive" corresponds to the words "immortal and soul". 


\section{Verb phrase}

It is ready to ruin our eyelashes

The ruined slap of the world collapsed (Hazin, 2005)

The more similar words there are, the more audible and resonant the music will be.

\section{Long lines}

The artist's art and the test of the power of his nature has not a better measure than a line ... Sometimes all the poems, sometimes two or three words has lines( Garkani, 1998: 316).

In such lines, the reader interacts more with the poet and may consider it his spoken language; because, a part of the poem, by guessing more words, becomes in harmony with the poet. These long lines give the reader more opportunity to accompany the poet in composing parts of the poem:

Who has seen only the heart that is stained with blood?

Our heart is stained with blood from head to toe (Hazin, 2005)

What happened when there was no wealth? What happened to the government tool? (Hazin, 2005)

What will do wisdom to my work? What will do wine to my hangover? (Hazin, 2005)

\section{Examples of the starting line}

In addition to playing a musical role, the early lines have also created a kind of defamiliarization and deviation from the norm; and the usual place of the line at the end of the verse has been changed to the beginning of the verse. Also, because of the location, the poet uses it to highlight his theme, thought and feeling. Another advantage of the first line is that by placing them at the beginning of each stanza and verse, the poet maintains the unity of a single tone and thought in the whole poem.

\section{It was time for a sad time}

Slanting the speech-making officer

It was time for the dragon goat

Arise a science 


\section{It was time to praise}

Passionate heart, breastfeeding (HAZIN, 2005)

In the above literature, the repetition of the phrases "it was time", "where", "lord" in the early parts, and the resulting music from the repetition of these words emphasizes, along with the consonance and syllable with other word.

\section{Complete homogeneity of two or more linguistic forms}

This means that in words, despite the proportion and homogeneity, there is a kind of duality in the word, construction and phonemes. This repetition emerges through the complete pun, the compound pun, and the verbal pun. At the beginning of the discussion, we will define the pun, its beauties and its artistic function.

\section{Pun}

"The concept of pun is any kind of commonality in the sounds and consonants of words that can show itself in various designs. In the essence and nature of each language, puns show itself as a linguistic law (Shafiei2000, 30).

Tajlil has done extensive research on puns, and has compiled his experiences and research in a book of the same name. He says in this regard: Pun is due to the similarity of the words that in all or some parts of them are associated with the song, and this association, which in turn evokes the meanings of the poems, causes a special pleasure in the listener ... Note which should be added here in the analysis of the beauty of puns; that puns is a show, of a kind of plurality but unity, because its words are united in form, while the meanings have variety and plurality, and these waves of verbal similarity and semantic difference create a special pleasure (TAJLIL, 1988, p. 1-3).

\section{Homophonic pun}

The industry of application is homonymous forms. Identical differences that differ from each other at least in terms of one of the morphological, syntactic or semantic roles (SAFAVI, 1930), which is considered the best type of pun. Because the effect of repeated letters and sounds is greater when they are in a larger unit. Repetition of similar components and syllables is beneficial for maximum sound effect of letters and sounds. 
The lips that do not cry is the lips of the grave

\section{Compound pun}

In a situation where consonant-syllable forms have different syntactic roles. The difference between the syntactic role and the change of the reliance position in two homogeneous forms is inevitable (SAFAVI, 2011, p. 303):

\section{I do not know what I did in the country of creation}

I know that I am the home of idol (Hazin, 2005)

You have a fried soul moth

You have a lot of discipline (Hazin, 2005)

In the above examples, puns, in addition to resulting music from the repetition of words, are also visually noticed.

\section{Incomplete lexical homogeneity}

Incomplete lexical homogeneity is the use of words in which phonetic similarity can be seen only in a part of two or more words.

\section{Rhythm}

As can be seen from the original books, the similarity of the words is in rhythm (balanced prostration), and the letter $\mathrm{z}$ (parallel prostration) or only in the letter $\mathrm{z}$ (pronounced prostration). Whenever this industry is mentioned at the sentence level, we will see the industries of embellishment, balance and similarity and guarantee of marriage.

\section{Incrustation}

It is recommended that (at least in two sentences) two items (parallel references) be placed in front of each other. In such sentences, the number of syllables is usually equal and on the same words (SHAMISA, 2007, p. 40-41).

Musical adornment makes the word very strong and doubles its effectiveness. Tarsi has the most complete rhythm and due to the presence of rhyme in the symmetries, the monotony rhythm affects the human soul and mind. For this reason, it plays a prominent role in developing the capacity of poetry through repetition. The most repetition can be found in ornate poems. 


\section{O prancer, heaven style}

Cloudy accelerator, expensive anchorage

To jump, the electricity is warmer

To go, softer mental flow (Hazin, 2005)

As it can be seen, the parallel syllables are placed in front of each other in pairs and have strengthened the music of the poem.

\section{Similar}

It coordinate two or more sentences by balanced reference contrast. This artistic creation creates a wide range of eloquence in order to repeat the phonetics of opposite symmetries in two stanzas, through which the music of rhythm, rhyme and line is completed.

It is a shame that their companions are on the same earth

It is a defect that they are synonymous under one sky

The words "shame and defect and companionship, of the earth and a sky" are balanced references that have created a special pleasure by repeating the phonemes of opposite symmetries.

\section{Parallel prostrations}

Consecutive words that are harmonious or homogeneous (homogeneous) or consonant (proportional). Sometimes there may be a small space between the words. This definition of lexical pairs will have the state of "observance of the like". He says that because this industry comes in a non-punitive form, it is a separate type; Safavi says that the most profitable way to use this industry is to use the extra fraction or inflection between two parallel prostrations (SAFAVI, 2011).

I was amazed at the leaves and the structure of the crowd

Many regrets for distress (Hazin, 2005)

From the way you look and the stare of beauty

I have wine in a cup and flower next to butler (Hazin, 2005)

We are loutish and give the wine

The corpses rise up, the souls rise up (HAZIN, 2005) 
In the above verses, the words "crowd, distress, way, look, beauty, corpses, souls, and uprising "have created a meaningful musical connection in each verse, as well as the repetition of identical consonants and vowels has caused audibility.

\title{
Rhyme
}

Rhyme "is an incomplete consonant that arises from the repetition of one or more sounds with the same sequence, at the end of the last unrepeatable words of the verses or verses of the poem, and sometimes before the line" (HAGHSHENAS, 2010, p. 62).

Repetition and its audio and musical value that mentioned earlier about rhyme, due to its special place at the end of the verses uses with pause, as well as part of the rhyme words regularly repeated in a poetic unit. The rhyme seems to be the center of gravity and support of the poem. The words that shine and are distinguished in the poem, especially if they are chosen in such a way that their consonants and vowels are more in line with other words of the poem on the one hand and with the line on the other. The music and the resulting coherence are doubled.

\section{Rhetorical Rhyme}

It is a rhyme in which one of the literary industries such as ingenuity, genius or innovation has been applied (SHAMISA: 2014, p. 127).

\section{Double rhyme}

A poem that has two rhymes. In such poems, the sound and musical properties of the rhyme are doubled. Because the repetition of four rhymes in the poem, offers a uniform and longer music.

\author{
The master was taught the master's method \\ Farhad's old trick is my homework \\ Every head of my hair is to give the chest a steel sticker to the field of love \\ (Hazin, 2005) \\ Looking for warmer electricity \\ Going to softer running water (Hazin, 2005)
}

As can be seen, in the first two verses, the repetition of the loud vowel "a" in the place of the rhymes has created the expected music, which, with the doubling the rhymes of 
"method, ax and sticker more beautiful; Especially since his letter is one of the ringing and resonant letters and are phonemes with other words in the verse; For example, style, practice, and in the next stanza with the words love and narration.

\section{Homogeneous rhyme}

Bringing all kinds of puns is in place of rhyme. There is a lot of evidence for rhymes that show a kind of pun in Lahiji book; this type of rhyme, in addition to its musical aspect, shows extra beauty in the company of a novel industry:

\section{Complete pun}

In complete puns is desired the same selection of phonetic elements from the replacement axis.

\section{O look at the heart of the game}

Eyelashes sentence in the game (Hazin, 2005)

The word "game" in the first instance means open hunting; but the repetition of this word in the second stanza is part of the verb. Pun in the place of rhyme strengthens the rhyme and increases its music, and due to repetition, more attention is paid to them.

\section{Lineraty pun}

The sun and the moon are not the mirror of beloved The glasses should be hijab if the sight is not blurred (Hazin, 2005)

In the example above, the rhymes of "beloved" and "sight" play the role of a musical part, also visually forming the genus of calligraphy.

\section{Heterogeneity pun}

\section{What you see in appearance is not real}

The view of critics is a veil of sleep in meaning (Hazin, 2005)

In this verse, the rhyme in the second stanza has one more syllable than the rhyme in the first stanza, which according to Shamisa, is called heterogeneity. 


\title{
Proportional rhyme
}

\author{
It is that the rhyming words fit together \\ The difference is between ghosts and soul
}

The population cries with soul (Hazin, 2005)

The two rhymes of ghosts "and" soul "fit together and evoke a special and unique body in the mind.

\section{There no One has description}

The very essence is indefinable (Hazin, 2005)

The two words "definition" and "description" are perfectly proportioned and both explain the subject and remove the ambiguity. In addition, the letter e is repeated several times in this verse.

\section{The faithful conscience left us}

Clear people left us (Hazin, 2005)

The proportion of the two words "clear" and "faithful" is of a general and specific type. In addition, the repetition of the vowel "e" and " $\mathrm{f}$ " has been added to the music of the beat.

There is no doubt that if the human brain is thirsty, it is thirst for understanding the facts and establishing a relationship between them.

\section{Contrasting rhyme}

Be my dog now that you are greedy

Otherwise, don't wear a pious dress (Hazin, 2005)

Hidden Egyptian razor and wooden stick

Is obvious before sharp arts (Hazin, 2005)

In the above verses, the words of greed, piety, plurality, unity, slow and fast, which play the role of music in the rhyme position, are also in contradiction with each other, and this contradiction and correspondence is associated with meanings and its significant expansion, value and it has given credit to this industry. 


\title{
Initial rhyme
}

\author{
The king who ran was Khair al-Anam \\ The month that ended on the sphere of excellence (Hazin, 2005) \\ The sky is warlike \\ The sun is setting slowly (Hazin, 2005)
}

In the above verses, the rhyme, in addition to the end of the verse, is also placed at the beginning of the stanzas

\section{Middle rhyme}

The dynamics of electricity amaze him

His shadow make enemy a dragon (Hazin, 2005)

In this example, the middle rhymes, like the rhymes in their original place and at the end of the verses, are in harmony with each other, so that the dancing of the repeated rhyming sounds has added to the richness of the verse music.

\section{Discussion}

The poet, with his imagination, emotion and feeling, enters and captures the familiar realities and presents his experiences in a different language. The basis of this poetic language is music. Terry Eagleton says about the Characteristics of Literary Works and the Role of Music in Distinguishing Literary Language from Everyday Language and the Set of Factors in Music Creation; Formalists know a literary work as a set of "arrangements." And these arrangements are: sound, imagination, melody, syntax, rhythm, rhyme, etc. The common denominator of all these elements is their "alienating" or "unfamiliar" effect, which the common language under the pressure of these arrangements reinforced, defined, summarized, selected and inverted, and the familiar world becomes unfamiliar; Thus, the formalists considered literary language as a set of deviations from the language of norm or a kind of linguistic outburst (IGELTON, 2012).the subject of literary science isn't literature but it is a factor that turns a specific effect into a literary effect. From this point of view, what forms the field of literary analysis is not the text, but certain provisions that have been used in the text (MAKARIK, 2014, p. 199). Shafiee Kadkani considers the factor of distinguishing the language of poetry from everyday language as song and balance and introduces a set of factors that cause the resurrection of words and the identification of words in language as a 
credit group (SHAFIEE, 2000, p. 8). Music has a special place in poetry. The source of which is the good composition and proportion and harmony between the words and the observance of proportion between them. In fact, it is an approach to presenting and shaping a literary work in which the poet, relying on his ability to use his linguistic capacities, highlights ordinary and everyday language. According to Shekolovski (1984-1893) "Literature can do something to make us see the world again, and to be strange again what has become familiar because of repetition" so that we can look at it again (BRETONS, 2009, p. 49).

In this regard, anything that creates a musical system in poetry and gives it a secondary meaning to poetry is called formalistic. In other words, formalistic can be examined in terms of balance at three levels: phonetic, lexical and syntactic, which results in the presentation of the musical form of the word in its broadest sense, and "repetition" is one of their salient aspects. In the meantime, the symmetry of syntactic and phonetic repetitions is of particular importance. For example, in the analysis of an article by Roman Jacobsen, Tadiyeh (2011, p. 46) says: "Repetition of a single grammatical form, along with repetition of a single phonetic form, is the constituent principle of a poetic work".

Jacobson says about poetry norm and value and rhythm of words: "Poetry is present when the word is felt as a word, not as a mere representative of the named object or the eruption of emotion, that is, when the words and their composition, their meaning instead of impartially referring to reality, their internal and external form finds its rhythm and value (HARLAND 2003, p. 237).

In Hazin Lahiji book, we are faced with many examples of de-familiarization at the level of regularization. The poet has done well in this matter by using the musical elements of the poem throughout his book. The lexical homogeneity of Lahiji's poems favorably highlights the music of his poems to the audience of his poetry. Using this rule, Hazin informs his audience about the minutes, subtleties and pure points of his poetry and prepares the minds and consciences of the audience to reach the poetic feelings and emotions through the accessibility and fluency of the word and by appropriate combination of words share the poetic experiences that are current in him. In fact, the power of Lahiji's words, along with the power of music in expressing and transmitting poetic emotions and thoughts, has expanded the power of inducing meanings. 


\section{Conclusion}

Hazin Lahiji has used various forms of verbal and phonetic repetitions in his book, and this feature has made his words unique, prominent and coherent. Hazin uses the regular distribution of phonology, rhyme, balance, proverb by creating the melody of letters in the consolidation and musical richness of his poetry; Also, by using different types of puns, such as complete puns and compound puns he shows the beauty of his words and by repeating the homogeneous and pleasing letters, along with other musical factors, adds to the richness of his poems and their phonetic prominence. Hazin, by various facilities of verbal innovations, while increasing the musical aspect of his words; it uses the other benefits of repetition to increase the taste of poetry and to make its audience more enjoyable, because the predictability that the listener feels about the poet's content creation, causes more attention and a sense of pleasure. Also, repeating the words in certain places of the verse makes the music more prominent and emphatic to the listener than usual. Hazin with these repetitions and the resulting music, eliminates the need for the listener to receive concepts in a conventional way and provides the listener new concepts with more impactful power. In examining the side music of Hazin's poems, it is observed that most of his poems have lines. The selected lines of the poet express his poetic experiences and emotions in a desirable way and complete the music of the poem with the proportions that they create with the rhyme and other words of the verse. It is worth mentioning that among the lines, sometimes there are lines that have no meaning, as if the poet, in getting rid of the usual conventions and criteria, embraces concepts that, through their rhythm, create a two-way connection with his audience, such as $\mathrm{Na}$ ha ho who is called "Zaum" by Russian formalists, and the rhymes used in his poems are often homogeneous and associated with a variety of puns; thus, the music resulting from repetition is doubled. In the beginning and in the intervals of the verses, we also encounter other rhymes that, in total, are coherent, musical, and enjoyable. They guarantee the hearing and accessibility of sad words.

It must be acknowledged that Hazin, by skillfully choosing and selecting words in appropriate spaces, in addition to creating double music in the presentation of concepts in a non-conventional and attractive way and creating coherence and accessibility in his speech and finally creating a homogeneous and effective literary system, and liberating words, from the fence of everyday life and automaticity, and creating a fit between selected and melodious words, with the expected meaning, has given a special distinction and prominence to his poems. 


\section{REFERENCES.}

AHMADI, B. Text structure and interpretation of text. 16. ed. Tehran: Markaz Publication, 2014.

ALIPOUR, M. The structure of today's poetry language. 3. ed. Tehran, Ferdows Publications, 2008.

ELIADEH, M. The myth of eternal return. Translated by Bahman Sarkarati. Tehran: Tahoori, 2005.

FARSHIDVAND, K. Critical theory of persian and arabic rhetoric techniques. Armaghan: Forty-Second, 1973. n. 11.

HAGHSHENAS, M. A. Linguistic literary articles. 2. ed. Tehran: Niloufar, 2011.

HARLAND, R. Literary theory from plato to barthes. 1. ed. Tehran: Cheshmeh Publication, 2003.

HAZIN LAHIJI, M. A. Hazin Lahiji Divan. 3. ed. Tehran: Sayeh Publication, 2005.

JAHAN TIGH, M. K. Sib bagh jan. 1. ed. Tehran: Sokhan Publications, 2001.

MAKARIK, I. Encyclopedia of contemporary literary theories. 5. ed. Tehran: Agah Publication, 2014.

NEWTON, E. Meaning of Beauty. 1. ed. Tehran, 1343.

RASRGOO, S. M. The art of speech design. 1. ed. Tehran: Samt Publications, 2003.

SABOOR, D. Afaghe ghazal farsi. 2. ed. Tehran: Zovar Publications, 2005.

SAFAVI, C. From linguistics to literature. 3. ed. Tehran: Surah Mehr Publications, 2011. v. 1.

SHAFIEE KADKANI, M. R. Poetry music. 6. ed. Tehran: Aghah Publication, 2000.

SHAFIEE KADKANI, M. R. The resurrection of words. 2. ed. Tehran: Sokhan Publications, 2012.

SHAMISA, S. A new look at badie. Tehran: Mitra Publication, 2007.

SHAMISA, S. Introduction to prose and rhyme. Tehran: Mitra Publication, 2014.

SHAMS AL-ULAMA GARKANI, H. M. H. Abda al-Bada'i., Hussein Jafari. 1. ed. Tabriz: Ahrar Publications, 1998.

TADIYEH, J. Y. Literary criticism in the twentieth century. Tehran, Surah Publications, 1998. 
TAJLIL, J. Pun in the field of persian literature. 1. ed. Tehran: Institute of Cultural Studies and Research, 1988.

\section{How to reference this article}

MORADGANJEH, D. N.; ZAHIRI NAV, B.; POURALKHAS, S. The role of lexical homogeneity in the poetry rhythm of Hazin Lahiji. Rev. EntreLínguas, Araraquara, v. 7, n. esp. 2, e021018, 2021. e-ISSN: 2447-3529. DOI: https://doi.org/10.29051/el.v7iesp.2.15144

Submitted: $05 / 01 / 2021$

Required revisions: 26/02/2021

Approved: 24/03/2021

Published: 01/06/2021 